\title{
PENGUATAN BANTUAN HIDUP DASAR PADA WARGA RW 09 PONDOK RANGGON, CIPAYUNG, JAKARTA TIMUR
}

\author{
Strengthening Basic Life Support for Residents of RW 09, \\ Pondok Ranggon, Cipayung, \\ East Jakarta \\ Muhammad Fandizal ${ }^{1}$, Yuli Astuti ${ }^{2}$, Dhien Novia Sani ${ }^{3}$, Dwi Septian Wijaya ${ }^{4}$, \\ Irsan $^{5}$, Uum Safari ${ }^{6}$, Neneng Eviana ${ }^{7}$ \\ ${ }^{1-7}$ Universitas Bhakti Kencana \\ $\underline{\text { muhammad.fandizal@bku.ac.id }}$
}

\begin{abstract}
ABSTRAK
Bantuan hidup dasar merupakan tindakan dasar untuk menolong nyawa seseorang dalam keadaan henti jantung dan henti napas. Kematian karena henti jantung dan henti nafas dapat diatasi bila korban mendapatakn pertolongan. Bantuan hidup dasar dapat dilakukan oleh siapapun dan dimanapun dengan segera disaat awal terjadinya henti jantung atau henti nafas. Tujuan kegiatan ini adalah untuk memberikan pendidikan dan pelatihan kepada masyarakat agar dapat mengetahui dan mendemonstrasikan pemberian bantuan hidup dasar pada kasus henti jantung dan henti nafas, tersedak, luka bakar, keracunan dan tenggelam. Pelaksanaan pendidikan dan pelatiahan diberikan kepada masyarakat di RT 09 RW 04 Kelurahan Pondok Ranggon Cipayung Jakarta Timur sebanyak 15 orang, pemberian materi dan pelatihan dengan metode ceramah diskusi disertai demontarasi dengan media power point dan manekin CPR (Cardiopulmonary Resuscitation) selama 30 menit, selain itu masyarakat diberikan pendidikan dan pelatihan korban tersedak, keracunan, luka bakar dan tenggelam. Hasil evaluasi pada pre test didapatkan tingkat pengetahuan sedang $46,7 \%$ dan rendah $53,3 \%$, sedangkan pada post test didapatkan tingkat pengetahuan tinggi $20 \%$ dan sedang $80 \%$. Progam pendidikan dan pelatihan bantuan hidup dasar yang telah dilaksanakan sangat bermanfaat untuk meningkatkan pengetahuan masyarakat sehingga diharapkan juga akan mampu memparktikkan pertolongan pertama pada kasus henti jantung dan henti nafas.
\end{abstract}

Kata Kunci : Bantuan Hidup Dasar, Pendidikan, Pelatihan, Penguatan

\begin{abstract}
Basic life support is a basic action to help someone's life in a state of cardiac arrest and respiratory arrest. Death due to cardiac arrest and respiratory arrest can be overcome if the victim gets help. Basic life support can be done by anyone and anywhere immediately when the onset of cardiac arrest or stopping breathing. The purpose of this activity is to provide education and training to the community so that they can know and demonstrate the provision of basic life support in cases of cardiac arrest and respiratory arrest, choking, burns, poisoning and drowning. The implementation of education and training was given to the people in RT 09 RW 04, Pondok Ranggon, Cipayung, East Jakarta as many as 15 people, giving material and training with discussion lecture methods accompanied by demonstrations with power point media and CPR (Cardio Pulmonary Resuscitation) mannequins for 30 minutes, in addition to the community given education and training for victims of choking, poisoning, burns and drowning. The results of the evaluation in the pre-test showed a moderate level of knowledge of $46.7 \%$ and a low of 53.3\%, whereas in the post-test obtained a high level of knowledge of $20 \%$ and a moderate of $80 \%$. The basic life support education and training program that has been carried out is very useful for increasing public knowledge so it is also expected to be able to practice first aid in cases of cardiac arrest and respiratory arrest.
\end{abstract}

Keywords : Basic life support, Education, Training, Strengthening

\section{PENDAHULUAN}

Setiap orang berisiko terkena musibah dan hal hal kegawatan yang waktu dan tempatnya tidak dapat diperkirakan. Setiap pribadi memiliki andil dalam memberikan pertolongan saat menemukan orang lain terkena musibah dan accident. Kebutuhan untuk pengenalan dan pembelajaran pertolongan pertama pada kasus 
emergency dan bantuan hidup dasar juga semakin tinggi mengingat angka kejadian kasus emergency yang terus meningkat setiap tahunnya.

Selain kegawat daruratan karena trauma, masih ada penyebab lain yang juga sering kali dapat berujung pada kematian, yaitu penyakit jantung. Dimana angka kematian akibat penyakit jantung di dunia tiap tahunnya mencapai 7,5 juta dan terus bertambah (Erawati 2015). Prevalensi jantung koroner berdasarkan wawancara terdiagnosis dokter di Indonesia sebesar 0,5 persen, dan berdasarkan terdiagnosis dokter atau gejala sebesar 1,5 persen. Sedangkan prevalensi penyakit jantung koroner di DKI Jakarta sebesar 0,7 persen pada umur $\geq 15$ tahun dimana Jakarta Selatan sebesar 0,6 persen berdasarkan wawancara terdiagnosis dokter dan sebesar 2,0 persen (tertinggi pertama di DKI Jakarta) berdasarkan terdiagnosis dokter dan gejala (Erawati 2015).

Kelangsungan hidup jauh lebih tinggi ketika korban OHCA menerima Cardiopulmonary Resusciation (CPR) atau Bantuan Hidup Dasar ( BHD ) segera dari bystander atau orang yang ada disekitar korban. Oleh karena itu menghubungi Emergency Call dan CPR yang diberikan segera oleh bystander dapat meningkatkan jumlah orang yang dapat bertahan hidup. Hal tersebut sejalan dengan beberapa data yakni: angka korban OHCA yang selamat oleh bystander sebesar 31,7 persen (Sudden Cardiac Arrest Foundation, 2015). Sedangkan menurut American Heart Association (2015) sebesar $40,1 \%$ korban OHCA terselamatkan setelah dilakukan resusitasi jantung paru (RJP) oleh bystander (American Heart Association, 2015).

Kematian karena henti jantung dan henti nafas dapat dicegah bila korban mendapatkan bantuan segera, jika seseorang yang terlatih resusitasi jantung paru (RJP) memberikan bantuan hidup dasar sampai dengan bantuan medis mengambil alih. Bantuan hidup dasar dapat dilakukan oleh siapapun dan dimanapun sesegera mungkin disaat awal terjadinya henti jantung untuk meningkatkan angka kelangsungan hidup (Suharsono dan Ningsih, 2009; Subagjo dkk, 2011).

Frame menyatakan bahwa Bantuan Hidup Dasar (BHD) harus diberikan pada korban- korban yang mengalami henti napas, henti jantung, dan perdarahan. Keterampilan BHD dapat diajarkan kepada siapa saja. Setiap orang dewasa seharusnya memiliki keterampilan BHD (Frame, 2010).

\section{METODE}

Kegiatan pengabdian kepada masyarakat ini telah dilaksanakan pada hari Sabtu dan Minggu tanggal 26 - 27 Oktober 2019 di RT 09 RW 04 Kelurahan Pondok Ranggon Kecamatan Cipayung Jakarta Timur. Pendidikan kesehatan dalam pengabdian masyarakat ini telah berlangsung dengan baik menggunakan metode ceramah diskusi disertai dengan demonstrasi. Metode ceramah dilakukan dengan menggunakan power point yang dibantu dengan LCD dan proyektor di depan masyarakat selama 30 menit kemudian dilanjutkan demonstrasi menggunakan manekin Cardiopulmonary Resuscitation (CFR) selama 10 menit, selain itu juga diberikan materi tentang pertolongan pada kasus tersedak, luka bakar, keracunan, tenggelam dan terakhir dilakukan tanya jawab atau diskusi serta diberikan kesempatan masyarakat untuk mempraktikkannya sendiri.

\section{HASIL DAN PEMBAHASAN}

Kegiatan pengabdian masyarakat dengan memberikan pendidikan kesehatan bantuan hidup dasar pada masyarakat di RT 09 RW 04 Kelurahan Pondok Ranggon Kecamatan Cipayung Jakarta Timur telah berlangsung baik (lihat gambar 1). Pertama kali dilakukan pengisian daftar hadir dan diberikan snack lalu acara dibuka oleh ketua panitia, ketua cabang Universitas Bhakti Kencana Jakarta dan ketua RT 09 pada pukul 09.00 WIB. Kegiatan telah berlangsung selama satu jam dan jumlah peserta yang hadir sebanyak 15 orang. Beberapa masyarakat khususnya kepala keluarga tidak bisa hadir seluruhnya oleh karena ada yang bekerja yang bersamaan dengan kegiatan pengabdian masyarakat akan tetapi seluruh kegiatan tetap berjalan lancar. Pada akhir kegiatan kembali ditutup oleh ketua panitia dan ketua RT 09 dan ucapan terima kasih dari tim pengabdian masyarakat program studi diploma tiga keperawatan Universitas Bhakti Kencana Jakarta. 
Tahap akhir pengabdian masyarakat dilakukan evaluasi untuk mengetahui pencapaian tujuan yang telah ditentukan. Setelah diberikan ceramah, diskusi dan demonstrasi bantuan hidup dasar maka dilakukan evaluasi kemudian diakhiri dengan pemberian leaflet bantuan hidup dasar. Teknik evaluasi dilakukan secara lisan dengan menanyakan langsung kepada peserta dan evaluasi dengan cara praktik yang dilakukan oleh peserta. Evaluasi pada kegiatan pendidikan kesehatan tentang bantuan hidup dasar yang diberikan pada masyarakat di RT 09 RW 04 Kelurahan Pondok Ranggon Kecamatan Cipayung Jakarta Timur sebagai berikut:

Tabel 1. Hasil evaluasi pre tes kegiatan pendidikan kesehatan tentang bantuan hidup dasar yang diberikan pada masyarakat di RT 09 RW 04 Kelurahan Pondok Ranggon Kecamatan Cipayung Jakarta Timur

\begin{tabular}{lcr}
\hline No & Tingkat Pengetahuan & Hasil \\
\hline 1 & Tinggi & $0 \%$ \\
2 & Sedang & $46,7 \%$ \\
3 & Rendah & $53,3 \%$ \\
\hline
\end{tabular}

Tabel 2. Hasil evaluasi post tes kegiatan pendidikan kesehatan tentang bantuan hidup dasar yang diberikan pada masyarakat di RT 09 RW 04 Kelurahan Pondok Ranggon Kecamatan Cipayung Jakarta Timur.

\begin{tabular}{lcr}
\hline No & Tingkat Pengetahuan & Hasil \\
\hline 1 & Tinggi & $20 \%$ \\
2 & Sedang & $80 \%$ \\
3 & Rendah & $0 \%$ \\
\hline
\end{tabular}

Berdasarkan tabel diatas menunjukkan hasil perbedaan sebelum dan sesudah diberikan pendidikan dan pelatihan bantuan hidup dasara kepada masyarakat. Pada tabel 1 sebelum diberikan pendidikan dan pelatihan bantuan hidup dasar, tingkat pengetahuan masyarakat rendah yaitu sebesar 53,3\% dan sedang 46,7\%. Kemudian setelah diberikan pendidikan dan pelatiahan bantuan hidup dasar, tingkat pengetahuan masyarakat tinggi sebesar $20 \%$ dan sedang $80 \%$. Berdasarkan evaluasi akhir maka terdapat perbedaan sebelum dan sesudah diberikan pendidikan dan pelatihan bantuan hidup dasar kepada masyarakat.

Hal ini tidak terlepas dari metode pembelajaran yang digunakan dimana dalam melaksanakan kegiatan ini selain menggunakan metode ceramah juga menggunakan media presentasi. Menurut Daryanto (2013) menyatakan bahwa pemilihan media presentasi yang disajikan berupa teks, gambar serta animasi yang dikombinasikan mampu menarik perhatian dari responden dalam melaksanakan pendidikan kesehatan sehingga dapat meningkatkan pengetahuan responden. Pada saat pelaksanaan kegiatan, responden terbilang baru mendapatkan pendidikan kesehatan menggunakan media presentasi dan demonstrasi sehingga responden memiliki keingintahuan besar dan sangat antusias. Media pembelajaran mampu mempengaruhi efektivitas pembelajaran sehingga mampu meningkatkan peserta didik dalam belajar dan mampu membantu meningkatkan penyerapan materi dan memfokuskan informasi pengetahuan (Arsyad, 2006).

\section{KESIMPULAN}

Peran serta masyarakat dalam mencegah kematian yang disebabkan oleh henti nafas dan henti jantung sangat penting mengingat kasus tersebut paling umum ditemukan di tengahtengah masyarakat dimana dan kapan saja, maka sangat perlu bagi masyarakat umum untuk mengetahui cara penanganan segera seperti bantuan hidup dasar (BHD). Selain itu penting bagi masyarakat memberikan pendidikan dan pelatihan pertolongan tersedak, luka bakar, keracunan dan tenggelam. Program kegiatan pendidikan dan pelatihan BHD yang telah dilaksanakan bermanfaat untuk meningkatkan pengetahuan masyarakat tentang BHD sehingga diharapkan juga masyarakat mampu mempraktikkan dan memberikan pertolongan pertama pada kasus henti nafas dan henti jantung, kasus tersedak, luka bakar, keracunan dan tenggelam dengan demikian angka kematian dan kesakitan dapat diatasi.

\section{DAFTAR PUSTAKA}

American Hearth Association (2015) 'Life Is Why'. Guidelines For Cardiopumonary \& Emergency Cardio Care. 
Arsyad, A. (2011) 'Media Pembelajaran cetakan ke-15'. Jakarta : Rajawali Pers

Arsyad, A. (2006) 'Media Pembelajaran'. Jakarta: Rineja Cipta

Erawati, P. (2015) 'Resusitasi Kardio Pulmoner (RJP) sebagai salah satu bekal keterampilan profesi guru pendidikan jasmani Riset'. Yogyakarta: FIK Universitas Negri Yogyakarta.

Frame, Scott B. (2015) 'PHTLS': Basic and Advanced Prehospital Trauma Life Support.

Lontoh, Christie, Killing, Maykel, Wongkar, Djon (2013) 'Pengaruh Pelatihan Teori Bantuan Hidup Dasar Terhadap Pengetahuan Resusitasi Jantung Paru Siswa-Siswi SMA Negeri 1 Toili'. Ejournal keperawatan, 1-5.

Pergola, A. M., \& Araujo, L. E. (2009) 'Laypeople and Basci Life Support.
Cardiopulmonary Resusciation'. 43(2):334-41.

Sugianto, Kartika (2013) 'Gambaran Tingkat Pengetahuan Perawat tentang Bantuan Hidup Dasar di RSUD Ciawi Bogor': FIK UI

Sudden Cardiac Arrest Foundation. (2015) Dikutip dari http://www.scaaaware.org/sca-news/aha-news/ahareleases-2015-heart-and-stroke-statistic pada tanggal 29 Oktober 2019.

Subagjo, A., Achyar, Ratnaningsih, E., Sugiman,T., Kosasih, A., Agustinus, R. (2011) 'Buku Panduan Kursus Bantuan Hidup Jantung Dasar'. Jakarta: Perhimpunan Dokter Spesialis Kardiovaskular Indonesia.

Suharsono, T dan Ningsih, DK. (2008) 'Penatalaksanaan Henti Jantung Diluar RumaH Sakit'. Malang: UMM Press. 